This PDF is a simplified version of the original article published in Internet Archaeology. Enlarged images which support this publication can be found in the original version online. All links also go to the online version.

Please cite this as: Oldham, M. 2021 Engagement, Sustainability and Diversity: examining recent heritage policy in Norway, Internet Archaeology 56. https://doi.org/10.11141/ia.56.12

\title{
Engagement, Sustainability and Diversity: examining recent heritage policy in Norway
}

Mark Oldham

\section{Summary}

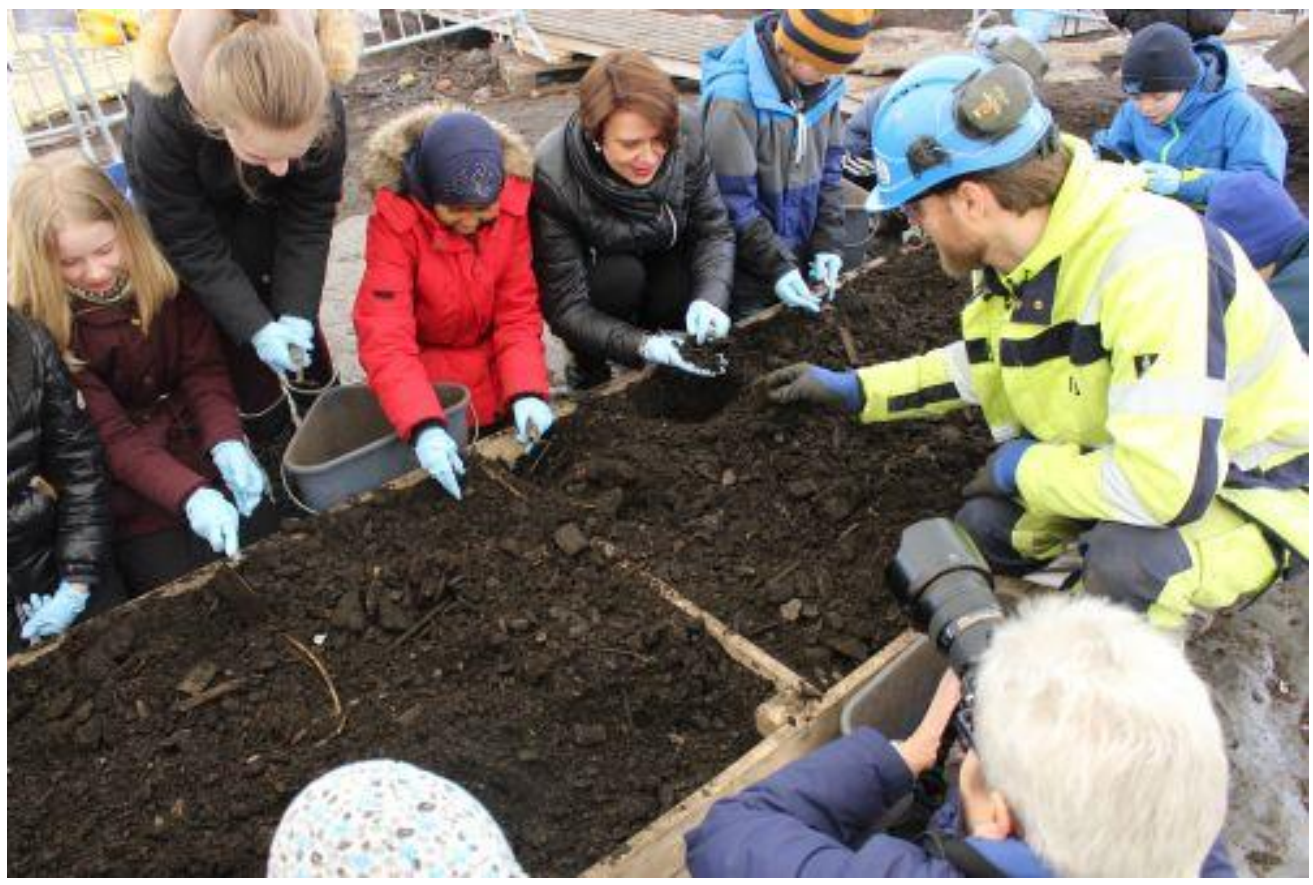

Children excavate archaeological remains (Photo: NIKU)

This article discusses recent Norwegian heritage policy and examines the three key terms of the most recent white paper - participation, sustainability and diversity - in light of the Norwegian government's key societal challenge of democratisation. 


\section{Introduction}

In 2020, the Norwegian government published a new white paper on cultural heritage: Nye mål i kulturmiljøpolitikken - Engasjement, bærekraft og mangfold (English: New goals in cultural environment policy - engagement, sustainability and diversity) (Det kongelige klima- og miljødepartement (henceforth referred to as KLD) 2020). Here, I will use a review of selected recent literature regarding participation, sustainability and diversity in archaeology and heritage to inform an analysis of the white paper's policy goals and how they meet the societal challenges presented therein, in particular democracy and democratisation. While Nye mål $i$ kulturmiljøpolitikken will be the key document, I will also refer to previous Norwegian policy documents within cultural heritage management, and the Norwegian museums white paper from 2021, Musea i samfunnet - Tillit, ting og tid (English: Museums in society - trust, things and time) (Det kongelige kulturdepartement (henceforth referred to as KUD) 2021). In addition, this study draws upon the fundamental pan-European conventions (e.g. Valletta and Faro) that structure and inform policy across Europe in the field of archaeology and heritage. As such, this article should be seen as an examination of a national attempt to implement European policy goals, with the associated need to adapt to the Norwegian political-bureaucratic and archaeological situation.

This article will firstly introduce the structure of heritage management in Norway, and the policy background to this white paper before examining the state of play with regard to archaeology and involvement, sustainability and diversity through a combined literature review and policy analysis. In conclusion, I suggest how the role of the professional archaeologist needs to adapt in order to meet the goal of a people-centred archaeology.

\section{Policy Background and Structure of Heritage Management in Norway}

Responsibility for heritage in Norway is divided between multiple ministries and directorates (Hølleland and Skrede 2019a, 129), with the Ministry for Climate and Environment and Directorate for Cultural Heritage having responsibility for tangible heritage, such as archaeology and historic buildings, and the Ministry of Culture and Arts Council Norway having responsibility for intangible culture and museums (with some exceptions). In addition, the regions and the municipalities have certain responsibilities within the sector, including decision-making powers, while other actors such as the university museums, the maritime museums and the Norwegian Institute for Cultural Heritage Research have specific roles, especially within the framework of developmentled archaeology.

The most recent significant change in the structure of Norwegian heritage management came about in 2020 as a result of the government's reform of regional government. The aim of this reform was to make the division of responsibilities between levels of government clearer and simpler, make bureaucracy more efficient and strengthen local democracy (Hølleland and Skrede 2019a, 131). One of the more direct consequences for cultural heritage management was the transfer of certain decision-making powers from the central authorities to the county administrations; as such, power was 
transferred to democratically elected and politically steered bodies and away from the national bureaucracy.

Subsequently, the new white paper Nye mål $i$ kulturmiljøpolitikken is placed within a setting of a need to solve three main challenges within society, namely, 'the green transition' to a more climate and environment-friendly society, democracy, and digitalisation (Figure 1) (KLD 2020, 21-23). These challenges structure much of the current government's overarching policy goals, independent of sector or responsible ministry, and hence this white paper presents the government's plan for using cultural heritage as a tool for solving these challenges.

It is in this light that we should see Nye mål $i$ kulturmiljøpolitikken, which follows 2013's Framtid med fotfeste: kulturminnepolitikken (English: Future with a foothold: cultural heritage policy) (KLD 2013) and 2005's Leve med kulturminner (English: Living with cultural heritage) (KLD 2005). In this new white paper, three broad new national goals are presented (KLD 2020, 7):

1. Everyone should have the opportunity to engage with and take responsibility for cultural environments.

2. Cultural environments are to contribute to sustainable development through holistic planning practices.

3. A diversity of cultural environments is to be taken care of as a basis for knowledge, experience and use.

The policy aims set out in the previous white papers are replaced by these new aims, and an existing term - cultural environment (kulturmiljo) - is given a new meaning as an overarching term in addition to its previous use in a much more limited manner as a specific category; the new term encompasses individual archaeological sites, areas with a series of related archaeological sites, and landscapes (KLD 2020,7). This change places cultural heritage much more in line with the other fields placed under the ministry, namely natural heritage management, and positions cultural environment policy as a part of climate and environmental policy (KLD 2020, 5, 7). This is important to note, and contrasts with the language and policies put forward in the museums white paper, written by the Ministry of Culture. 


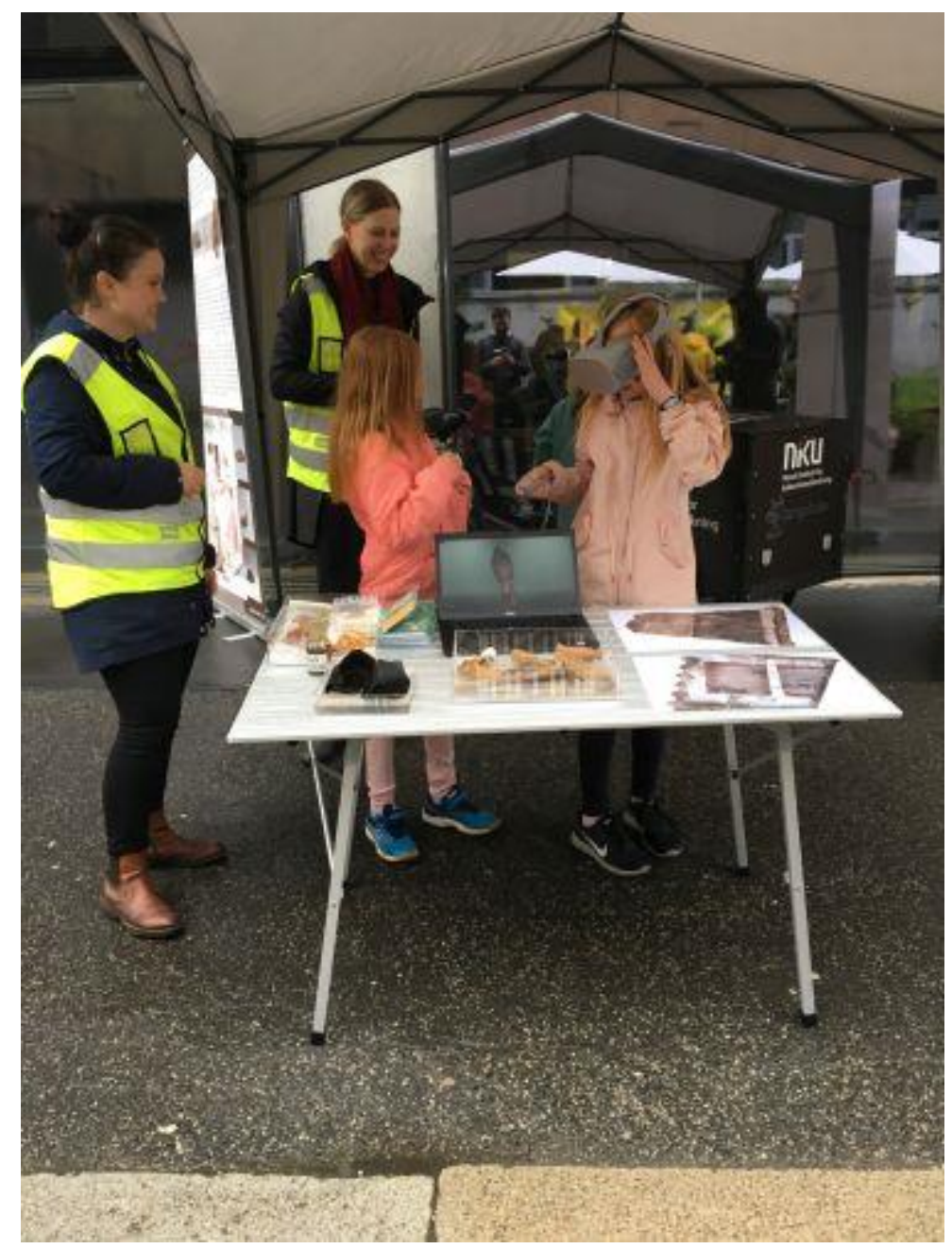

Figure 1: Children explore finds and sites using Augmented Reality technology (Photo: NIKU)

Nye mål $i$ kulturmiljøpolitikken also acts to further implement the European Convention on the Protection of the Archaeological Heritage (Council of Europe 1992), known as the Valletta Convention, into Norwegian heritage policy and practice. As noted, the Valletta Convention 'sets standards for securing archaeological heritage as a source for the shared European memory and as an instrument for historical and scientific study' and 'provides guidelines for the integration [of archaeological heritage] in the planning process, the financing of excavations, collection and dissemination of scientific data and awareness-raising' (KLD 2020, 31).

Furthermore, the White Paper also acts upon the Framework Convention on the Value of Cultural Heritage for Society (Council of Europe 2005), known as the Faro Convention, and the European Landscape Convention (Council of Europe 2000). It can be said that these two conventions are directly connected to the idea and challenge of democratisation (KUD 2021, 21), and specifically the national aim of everyone having the opportunity to engage with and take responsibility for cultural environments (KLD 2020, 7). For example, in the preamble to the Faro Convention (Council of Europe 2005), we are told that the signatories recognise:

the need to put people and human values at the centre of an enlarged and crossdisciplinary concept of cultural heritage; 
recognise:

that every person has a right to engage with the cultural heritage of their choice, while respecting the rights and freedoms of others

and are convinced:

of the need to involve everyone in society in the ongoing process of defining and managing cultural heritage;

Hence, the key challenge that the white paper addresses, and one that will be directly addressed in this article, is democracy - and in particular the way in which participation can be equated with democratisation. As stated in the white paper (KLD 2020, 22):

democracy and democratisation are to a large extent about participation and the ability to influence. Everyone has the right to take part in the heritage that they themselves choose, at the same time as respecting others' rights and freedoms. Thus, cultural heritage creates an arena for democracy-building, participation, and a culture of expression. Cultural heritage concerns everyone.

The democratising discourse in Norway, however, has certain important differences from that we see discussed by international heritage scholars (e.g. Kiddey 2020, 27). Rather, the individualised conception of democracy is implemented through representative democracy and the legal and democratic channels through which one has the opportunity to participate in and influence planning and other democratic processes. As Hølleland and Skrede have pointed out (2019a, 139):

In Norway, democracy and democratisation implies delegating power and authority to elected bodies, whereas the majority of contributions within international cultural heritage research is to a much greater extent about democratisation in an apolitical and emancipatory sense. Here, individual rights are promoted with no elected bodies standing in the way of one's own priorities.

As a result, one can see that there is a gap between what one might call the majority interpretation of the intentions of, for example, the Faro Convention, and the Norwegian 'translation' into national policy. Indeed, the main focus of critiques of this policy from Norwegian heritage actors is that it is a politicising of heritage (Hølleland and Skrede 2019a, 136), rather than an alternative interpretation of the concept of democratisation. This is nevertheless interesting, and to a large extent something that is lacking from the broader international debate on democratisation, which generally fails to acknowledge the role and position of heritage management and bureaucracy in facilitating democratisation - no matter how it is defined. As Hølleland and Skrede have pointed out (2019a, 136):

The Norwegian discussion on politicisation thus makes visible how the democratisation of cultural heritage is also an interaction between management and political steering. This separates the Norwegian politicisation discussion from debates on democratisation that are happening on the international level, where democratisation is equated with an ideal of unrestricted (individual) freedom to participate in discussions about heritage without the landscape of heritage management being included to any great extent. 
This Norwegian interpretation of democratisation in international policy and debates can also be seen in how the white paper integrates the European Cultural Heritage Strategy for the 21st Century (Council of Europe 2018), which encourages participatory management and a greater role for citizens (Council of Europe 2018, 22) and argues for a democratisation of heritage, where values are not (solely) determined by the expert or the heritage authorities - in contrast to the listing fetish that consumes much of heritage management and policy (see below):

heritage is no longer limited to those elements officially recognized as such by national authorities - the protected heritage - but now includes those elements regarded as heritage by the local population and local authorities. This development prompts new, more participatory and more collaborative management approaches (Council of Europe 2018, 8).

The aim expressed above, of a people-centred heritage, has been discussed more generally as 'dialogical democracy', whereby 'emphasis is placed on giving "nonexperts" the opportunity to take part in decision-making processes' (Hølleland and Skrede 2019b, 827). This is a well-established principle within Norwegian democracy, notably in relation to planning matters, known as medvirkning; as such it is natural to extend this principle to cultural heritage matters, and thus provide for democratisation within the Norwegian setting.

Democratisation of heritage has become a key theme in international discourse (Hølleland and Skrede 2019a, 133), whereby the power to define heritage is shifted from a narrow group of experts to various publics. For example, recent work (Fredheim 2018; Richardson 2017) has argued that we must consider how we can facilitate democratisation and participation without reinforcing existing power structures. This desire to make heritage more inclusive can be said to be an implementation of nonrepresentational theory, emphasising 'people's right to feel and articulate heritage through feelings, without any expert telling them what to value' (Hølleland and Skrede 2019b, 827). This, in many ways, builds upon previous research in community archaeology and heritage, and in particular the nature of community - both as a group of people and as rhetoric - and how this relates to power and what Smith described as the Authorized Heritage Discourse (AHD) (Smith 2006; Smith and Waterton 2009). One of the aspects highlighted (e.g. Fredheim 2018) that is particularly relevant is the nature of this 'empowerment'. This is a concern that one can express regarding the goals of Nye mål i kulturmiljøpolitikken (my emphasis):

The government will facilitate for partnership and collaboration with all citizens, as a part of the follow-up of the Faro Convention. The government's ambition is that more people will feel ownership and take responsibility for cultural environments. Cultural environments are a shared good, and a shared responsibility (KLD 2020, 35).

The nature of this transfer of ownership and responsibility is not expanded upon, but given the 'local' Norwegian interpretation of democratisation presented earlier it is likely to be through existing processes and democratic structures. The regional reform discussed above aims to move decisions about heritage to an elected level closer to citizens (Hølleland and Skrede 2019a, 134), and thus by involving the demos of a region in decision-making by placing responsibility with their elected representatives, the government fulfils the goal of more involvement and responsibility through representative democracy and established local and regional government processes. 
Increased participation through other means is also a key goal in Nye mål $i$

kulturmiljøpolitikken, but with the forms of participation presented as a binary alternative: 'Participation can be exercised individually through personal, non-organised interest, or through organisations and regulated participation processes' (KLD 2020, 22). The goal of increased participation echoes the findings of the pan-European NEARCH survey, which showed a clear tendency that people are generally interested in archaeology and heritage, but that they want more involvement (Kajda et al. 2017, 107). Many want to visit or take part in archaeological investigations and meet archaeologists in order to better understand the archaeological profession - and to better understand archaeology's usefulness for their community (Kajda et al. 2017, 103). A majority would also like to be more involved in the decision-making processes surrounding archaeological projects in their local area. The public also want knowledge about archaeology to be disseminated in a more accessible manner and want more opportunities to co-operate with archaeologists (Kajda et al. 2017, 107). Participation and involvement seem to be desired - but not necessarily fully provided for.

\section{Participation, Involvement and Engagement}

The first national goal of Nye mål $i$ kulturmiljøpolitkken:

emphasises people's right to have a cultural heritage and that the cultural environment is a shared good that is a shared responsibility to manage. The goal also underlines that everyone should have the opportunity to get involved. The state's responsibility is to best facilitate this (KLD $\underline{2020}, 8)$.

This goal is very much based on the ideas set out in the Faro Convention and the connection made between heritage and rights (and thus democracy). As stated above, participation is to be encouraged, but is to be facilitated by the state. The framework for this involvement and engagement is yet to be determined, but the white paper acknowledges that there is no single way to involve people:

Participation and co-creation are important for cultural environment management. In order for citizens to experience [heritage] as something engaging, relevant and useful to be involved in, it is crucial that methods and tools match the target group (KLD 2020, 39).

However, participation is an elusive concept, as Kelty has noted (2017, 77): 'On one day, participation is the solution to our most practical concerns or even an ethical calling; on the next day it is a containment strategy designed to keep us chillingly in place'. By tying participation in heritage together with democracy and rights and responsibilities, the government is co-opting participation for the broader societal benefit. As stated in Musea i samfunnet:

Our museums are expressions for the development of a society, a nation's self-esteem, the standard of freedom of expression and democracy in a community. Museum institutions are democratic keystones, a part of the crucial infrastructure for democracy and free speech (KUD $\underline{2021}, 7$ ). 
Participation, like archaeology (Almansa Sánchez 2018, 203), is hence often seen as 'a normative good' (Kelty 2017, 81), and as a form of legitimisation (Stevenson et al. 2017); instead, it ought to be viewed as a personal choice where participation and nonparticipation are equally valid; participation should be driven by personal attachment (May 2020, 75) or desire rather than feelings of guilt or needing to fit in. Furthermore, the participation discourse tends to fix communities to a place; this is not necessarily helpful, especially as more and more of these 'empowerment' opportunities take place online (such as crowdsourcing, see Bonacchi et al. 2019). Indeed, we see the contours of this fixing and structuring of participants in Nye mål $i$ kulturmiljøpolitikken by the reference to participation through organisations and regulated processes (KLD 2020, 22). As such, it is important to move away from seeing community groups - and indeed participation more widely - as an 'explanation or solution' (Waterton and Smith 2010, 5), and instead acknowledge and understand the relationships and power imbalances inherent in participation and people-centred archaeology. Changes are therefore unlikely to come about if the overall structures remain the same, and therefore a people-centred approach, while well intentioned and welcome, is nevertheless difficult to achieve. As Hølleland and Skrede $(\underline{2019 b}, 827)$ recognise:

Good intentions may be compromised by lingering realist or logical-positivist underpinnings of disciplines such as archaeology which provide premises for legislation and policies concerning management. Moreover [people-centred approaches] may be seen as empty gestures wherein participants become passive beneficiaries and experts achieve, or re-establish, the position of active subjects 'making things happen' and determine what is valuable heritage.

Linked to the idea of increasing participation, and the proposals and goals set out in both the Valletta and Faro convention texts, strategies, and Norwegian white papers, is an increased role for volunteers and voluntary work. This is not, however, the straightforward positive that is often presented. Richardson, for example, has forcefully argued that the replacement of professional positions with volunteers is 'a fast track to the devaluation of skills and knowledge' (Richardson 2017, 313); such a move is inherently anti-meritocratic and undemocratic, leaving the profession only open to those that do not have to earn a living from it. Furthermore, it has been argued that 'heritage professionals, scholars and volunteers would do well to be wary of new "democratising" initiatives intended to double as relief for pressurised institutional budgets'

(Fredheim 2018, 620); thus, we need to ask whether the recent focus on volunteering including that in recent Norwegian white papers (KUD 2018; KLD 2020; KUD 2021) - is real or whether it is just an alternative funding solution. As noted above, the policy set out in Nye mål $i$ kulturmiljøpolitikken suggests that the voluntary sector will have to carry at least some of the burden for maintaining cultural heritage:

The overarching volunteering policy goal is that participation shall be broad and large, and that volunteering should create interest, community, integration and cultural awareness. In the voluntarism white paper it is noted that 'Community responsibility stands as a key word for voluntary organisation. Not just social responsibility, but also responsibility for one's neighbourhood and heritage' (KLD 2020, 37).

Volunteering may thus be envisioned as a transfer of responsibility, but without the transfer of control - inferred also by the reference to the state facilitating participation (KLD 2020, 8). Such a transfer can perhaps be better considered as 'a new form of 
control enacted through processes of collaboration' (Fredheim 2018, 624). Indeed, as Kelty $(\underline{2017}, 88)$ acknowledges,

we sometimes speak of participation as a purpose, an end that we assimilate to democratization or liberation; but it is just as often implemented as a means to achieve goals that turn out to be inconsistent with that purpose.

Often, professional archaeologists, acting as 'stewards for the past' (Waterton and Smith 2010,12), manage and take the lead in processes of 'community participation' and 'stakeholder dialogue' (Fredheim 2018, 624) and are required to guide grassroots organisations by managing archaeological participation and overseeing analysis and interpretation (Richardson 2017, 310). Furthermore, the professional archaeologist is often also the gatekeeper, determining the acceptability of a project and the extent to which it should receive funding or even perhaps permission to go ahead; one can see the potential for such gatekeeping with the idea that the state shall facilitate participation, as set out in Nye mål i kulturmiljøpolitikken (KLD 2020, 8). This often results in relatively passive roles for the non-expert public. Projects are inevitably tailored to suit the requirements of the archaeologist and the heritage bureaucracy rather than the needs of the public, and as such can be a co-option of 'grassroots' or 'community' archaeology (Richardson 2017, 310). Hence, efforts to increase public participation in heritage should be seen in a more critical light (Fredheim 2018, 625); the deficit model (e.g.

Merriman 2004), whereby the public is seen to be lacking the knowledge that the expert provides, still looms large in much of the interaction between archaeologists and the public.

Nevertheless, Nye mål i kulturmiljøpolitikken reconfirms the polluter pays principle and the role of development-led archaeology within cultural heritage management, as set out in the Valletta Convention and the Norwegian Cultural Heritage Act (KLD 2020, 28). This is a key element in ensuring that the information value of the archaeological record is retained when development impacts archaeological remains, and thus the idea of public benefit that is inherent in this principle can be operationalised to achieve the three national goals that are set out in the white paper (KLD 2020, 7). There is clear untapped potential for public engagement with archaeology in relation to development-led archaeology, which is the most common form of archaeology but yet arguably the least visible for most people. Indeed, public engagement is too often not seen as part of the whole of the archaeological investigation - in contrast with the aims of the Faro Convention. In addition, the project-based nature of this work tends to result in a shortterm boost in interest that sometimes fails to have consistent results or lasting effects; Wahlgren and Svanberg $(\underline{2008}, 252)$ have noticed this in Sweden, where:

The problem is not primarily a lack of interest in communicating results but the difficulties of integration between public projects and ordinary archaeological work. Public engagements tend to be added on the side instead of becoming parts of what is significant for archaeology and its results.

Hence, we see that public engagement is too often considered something that is nice to do if there is time, rather than a fundamental part of the archaeological project. This failure to give public engagement equal weight creates a vicious circle that makes it more difficult to promote an integrated approach when all focus is on carrying out the excavation and the everyday administration involved in dealing with clients, the authorities, employees and so on. There is undoubtedly the potential to reorganise 
development-led archaeology to be more socially focused (Figure 2) - in line with the policy set out in Nye mål i kulturmiljøpolitikk - but budgetary and bureaucratic constraints often make this difficult (Almansa Sánchez 2013, 10); indeed, in many cases, dissemination and public engagement is limited by the requirements/conditions of contract with the developer - and limited to that which has been described as 'old territory': talks, site visits and mock excavations (Almansa Sánchez 2018, 202).

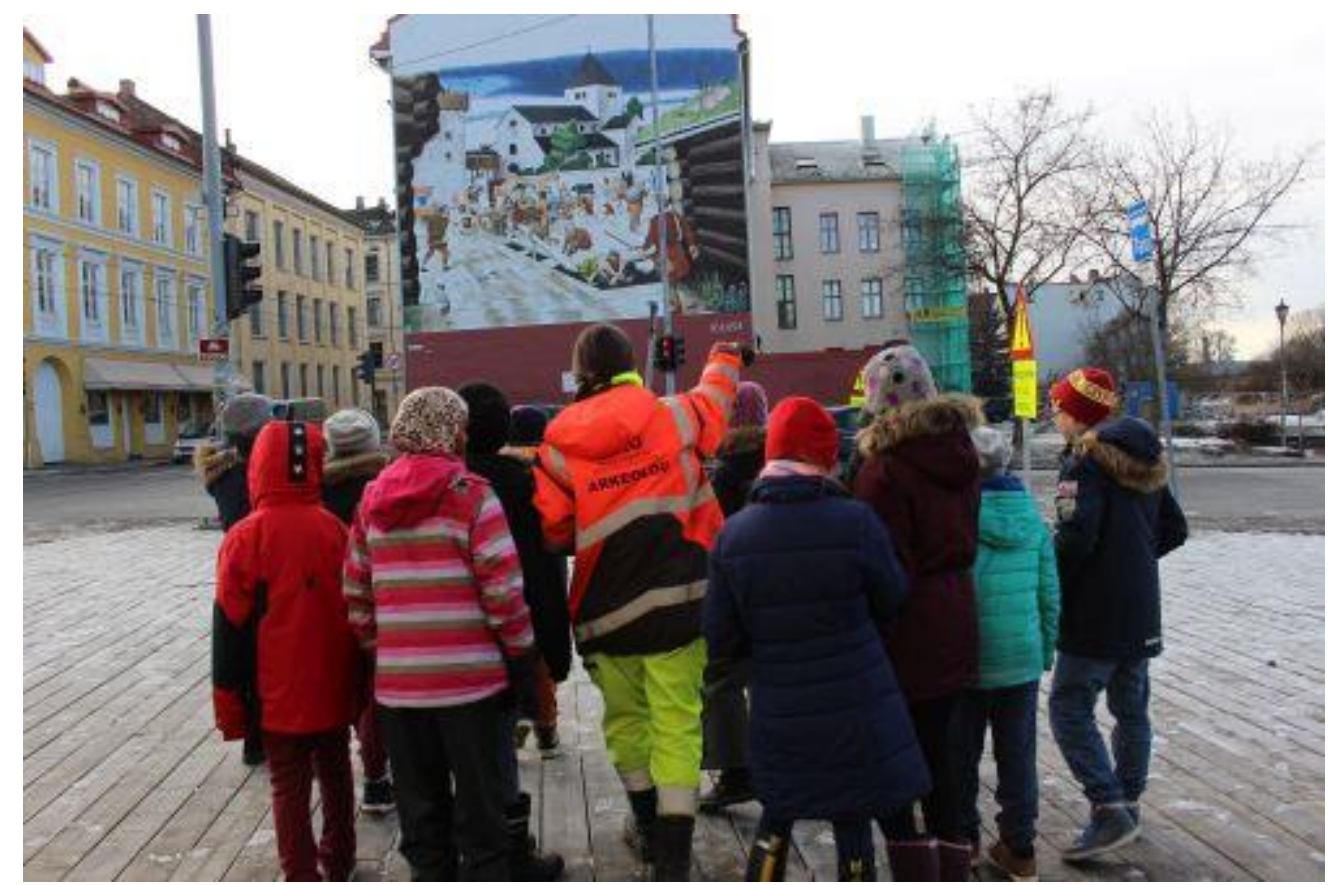

Figure 2: Schoolchildren are introduced to Medieval Oslo (Photo: NIKU)

\section{Sustainability and Development}

The second national goal in the white paper:

shows the significance of the planning process for maintaining a diversity of cultural environments and how these [cultural environments] can contribute to environmental, social and financial sustainability. The goal underlines Norway's responsibility for and the government's ambitions of following up the UN's sustainability goals and Agenda 2030 (KLD 2020, 8).

Hence, Nye mål i kulturmiljøpolitikken has a clear development focus - and is explicitly connected to the UN's development goals and the three subdivisions of environmental sustainability, social sustainability, and financial sustainability (KLD 2020, 50). In particular, it is the way in which social sustainability is expressed that has the key relevance to the other goals of the white paper, namely involvement and diversity, as for example it is stated that:

Cultural heritage's potential for achieving social sustainability lies mainly in the significance heritage has for identity, belonging, quality of life and heath for all (KLD 2020, 54).

And: 
Cultural heritage can provide insight into and knowledge about cultural diversity in time and space. It can contribute to increasing understanding for the present and historical developments, that again can form a basis for greater acceptance of cultural differences. Cultural heritage is in this way a resource for integration and inclusion (KLD 2020, 54).

The recent white paper on museums Musea i samfunnet (KUD 2021) has a similarly strong focus on the role of heritage as a tool for development. This is also the case when looking at other Norwegian policy documents as well, which often position cultural heritage in terms of 'value creation', 'resource management' and 'solutions'. For example, the Norwegian Directorate for Cultural Heritage, in its strategy document for 2017-2021 (2016-17, 5), states that:

The Directorate is responsible for ensuring that the full breadth of Norway's cultural heritage is managed as resources for continued active use and as a repository of knowledge, to provide opportunities for experiencing the cultural heritage, and as a basis for value creation.

And furthermore (my emphases), that (2016-17, 7):

To ensure that people accept the legitimacy and importance of cultural heritage conservation, Norway must manage its heritage so that it becomes a valuable resource and part of the solution to the challenges society is facing today. (...) It is important to raise awareness of cultural heritage values in the public debate. The Directorate intends to document and communicate information about the benefits society can derive from the cultural heritage and how Norway can use its heritage to promote sustainable development. (...) This may also make it possible to argue more strongly for the importance of incorporating cultural heritage considerations in the context of social development.

This focus on archaeology and heritage as sustainable development is echoed by the NEARCH survey, where the focus (both national surveys and the broader survey in Kajda et al. 2017 and Marx et al. 2017) was very much within the development paradigm, and in other European discussions and policy documents, which tend to place archaeology within the framework of sustainable development (see also Kajda et al. 2017, 109).

Indeed, much current Norwegian policy - across all sectors - is based on the importance of meeting the development goals set by the UN

(see https://www.regieringen.no/no/tema/fns-barekraftsmal/id2590133), and sustainable development more generally is a key factor in cultural heritage policy. This reflects a long-standing commitment to the cause of international development and of potential socioeconomic benefits of cultural heritage for society as a whole, which was arguably transformed into a key strand of policy through the work of former Norwegian Prime Minister Gro Harlem Brundtland and the concept of sustainable development presented in the Brundtland Report (World Commission on Environment and Development 1987).

\section{Diversity and Representativeness}

Nye mål i kulturmiljøpolitikken's third national goal: 
underlines that a diversity of heritage sites, cultural environments and landscapes are to be taken care of as resources and the basis for knowledge, experience and use (KLD 2020, 8).

Diversity, however, must also include the diversity of the profession; an overwhelmingly white/Norwegian profession will struggle to include and present stories of people with different backgrounds. As noted above, previous research has shown that an inclusive archaeology remains elusive (Kajda et al. 2017, 100), but we see in the recent museums white paper that there is an awareness of this and a desire to change the situation, at least within the museums sector:

Actively inviting other voices and other viewpoints into the museum contributes to the museum's power of definition being challenged, and it opens for new perspectives on the collections and the contexts they can be part of (KUD 2021, 62).

Museums must to a greater extent meet users where they are and on their premises, and that involves expectations of greater access, room for dialogue and participation, and also through new channels and platforms for knowledge-sharing (KUD 2021, 65).

Nevertheless, a diversifying of the profession is not part of either of the white papers addressed here, and there has up to now been little focus on the diversity of either the profession or the people that we work with. Data from the UK shows that both volunteers and the workforce are overwhelmingly white (99\% of workers, $95 \%$ of volunteers) and tend to live in more affluent areas than the national average (Fredheim 2018, 623); there is little data on this from Norway, but one would not be surprised to see similar figures here too. As such, some have argued that it is difficult to equate 'the people' with those who archaeologists tend to work with (Gonzalez Ruibal et al. 2018, 508), and thus we ought to question whether we are guilty of making assumptions about the resources and values needed to participate in heritage projects, such as education, financial means, national and aesthetic values and so on (Waterton and Smith 2010, 10). Furthermore, it has also been argued that we too often confuse visitor data - and in particular the social and ethnic composition of visitors - with 'extending the idea of what heritage is' (Smith and Waterton 2009, 12). Hence, the call to diversify collections from Musea $i$ samfunnet is encouraging:

In the same way that it is necessary for collections at museums to represent the diversity of the people in the country and the stories they carry, it is crucial that museums in their dissemination strive for variation and breadth in their themes, approaches and forms. Diversity as a value involves making visible and valuing that we have differing voices and perspectives that can add something positive to society and expand understandings of, and stories about, us all as a greater whole. The shared conversation spaces for reflection and opinion-forming are essential in a democracy. The critical, public debate is more important than ever. Letting the users in is an important part of this. That many voices from various backgrounds, ages, genders etc. participate in these spaces is crucial (KUD 2021, 59).

The proposals in both Musea i samfunnet and Nye mål $i$ kulturminnepolitikken hence share a desire to increase participation - both in numbers and in terms of who participates. As noted in the museums white paper (KUD 2021, 57): 
it is necessary that this work is given greater focus in the whole sector going forward. As a part of this, it is required that museums develop more knowledge about who visits them, who seldom or never does, and the hindrances that can cause this. Through targeted work at specific groups of users and non-users, museums can succeed in becoming relevant for even more people.

However, one must be wary of the homogenising nature of the grouping of people into communities, which masks internal differences and smooths out rough edges. Indeed, it can be argued that the sector's conception of community is both simplistic, romantic and nostalgic, and universalised (Waterton and Smith 2010, 5-6, 10).

It can also be said that much archaeological and heritage work in relation to communities is done for them rather than with them (Waterton and Smith 2010, 7). This paternalistic attitude suggests that we get involved with communities because it makes us feel good, rather than for community benefit. Furthermore, it is often the case that this work is one-way, non-inclusive, and involving the usual kinds of people - the ones that are easiest to reach: the white middle class, with the time and resources to get involved. Archaeology's audience is equally as non-diverse as the profession, and thus by institutionalising this idea of community, that of the people we are to engage with as being like us, but not professionals, we actively exclude other groups and subordinate them; their heritage is interpreted, made secondary to majority heritage, or even rejected (Waterton and Smith 2010, 8, 10).

In our attempts to become more diverse and inclusive, however, we should be critical about the process of inclusion; power imbalances and normalising processes are again in play here, and, as Smith and Waterton have argued, one should be wary of 'attempts by "mainstream" heritage organisations to persuade excluded groups to buy into and accept dominant understandings of heritage' $(\underline{2009}, 32)$. The management of participation and involvement should also be reflected upon; despite the positive intentions, this has the potential to exclude through 'governance networks' (Fredheim 2018, 627) making support contingent on certain conditions. This needs to be at the forefront when considering the implementation of the policies set out in Nye mål $i$ kulturmiljøpolitikken. Furthermore, the transformation of heritage into 'a vehicle for social change' (Fredheim 2018, 627), which is an inherent part of increasing inclusivity and democratisation, may struggle in the face of conservative forces - both within heritage management and the established voluntary sector - that are concerned with maintaining their positions of power. As we have seen in recent times, archaeology and heritage despite being something that is all too often packaged as cosy, familiar and nonthreatening, rather than dissonant and contested - is by no means resistant to the social conservative backlash and ongoing 'culture war' that we see happening around us. Hence, it is clear that the inclusion of subaltern stories in archaeology and heritage is not stress-free, but inclusion can arguably only occur once exclusion and diversity are acknowledged (Smith and Waterton $\underline{2009}, 108$ ); this requires community engagement and, as such, working together with communities (Figure 3 ) is an ethical responsibility for archaeologists (Atalay 2012, 44). 


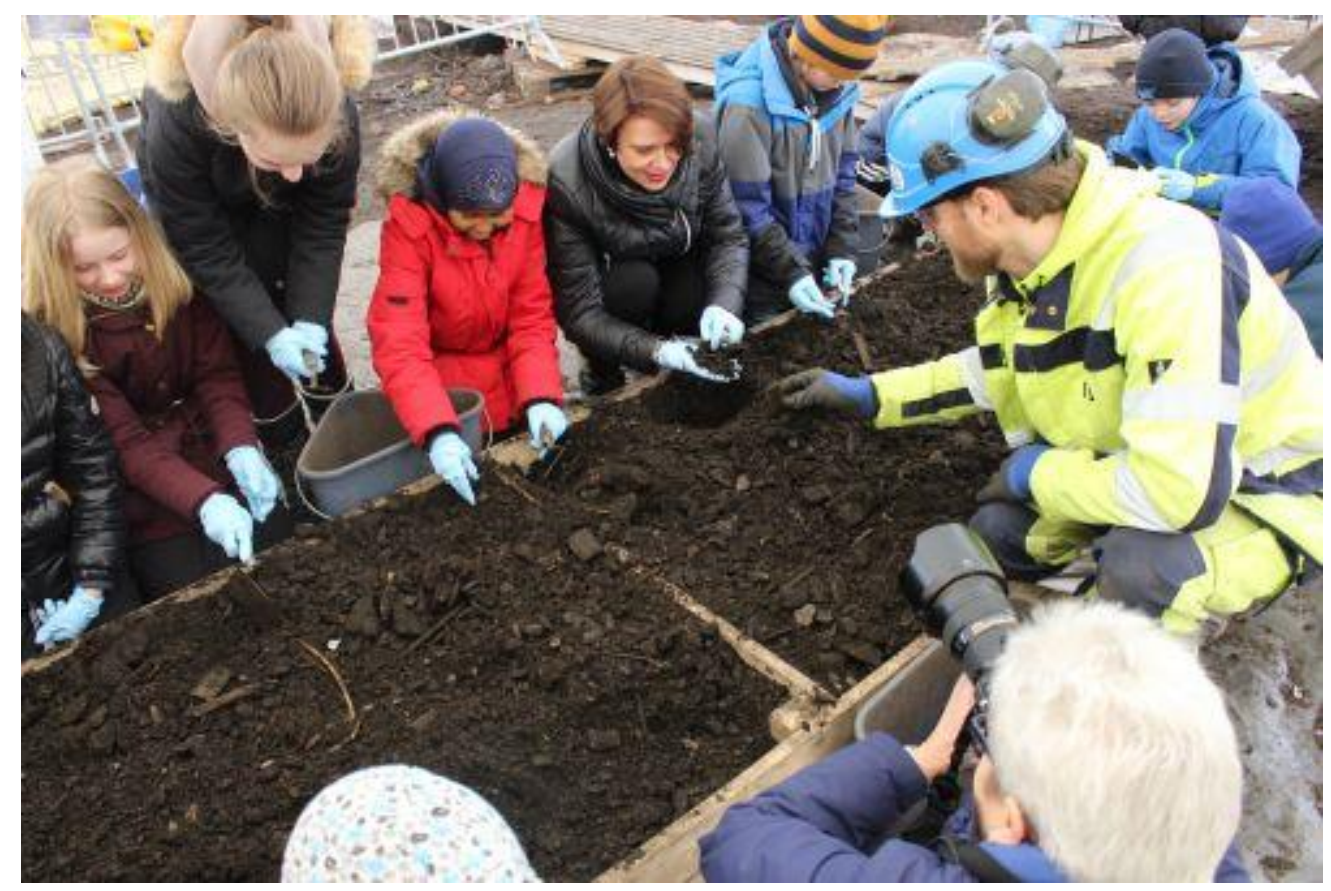

Figure 3: Children excavate archaeological remains (Photo: NIKU)

However, it is not diversity and representativeness of people that is in focus in Nye mål $i$ kulturmiljøpolitikken, but diversity and representativeness of sites, environments and landscapes; as mentioned earlier, this policy document positions cultural heritage closer to natural heritage and nature management and concepts such as endangerment and biodiversity. It would appear, however, that this goal of a diversity of things is also difficult to achieve. Despite broad popular interest, and frequent new policymaking, archaeology is in a precarious position, suffering from cuts and funding shortages: even in Norway, the heritage authorities are under constant pressure to find annual savings as part of the government's de-bureaucratisation and efficiency reform (ABE-reformen) and minimise costs for developers, and the recent regional reform transferred tasks and responsibilities without the attendant funding. Furthermore, goals for limiting the loss of heritage sites are watered down, as one can see when comparing recent policy documents. In the white paper of 2005, Leve med kulturminner (KLD 2005), the Norwegian government aimed to reduce the annual loss of heritage sites to $0.5 \%$ per year by 2020. In the subsequent white paper, 2013's Framtid med fotfeste (KLD 2013), it is noted that there is a real risk that this goal will not be met. By October 2016, and the publication of the Directorate for Cultural Heritage's Strategy 2017-2021, the aim was reformulated as 'Losses of cultural monuments and sites will be minimised' (2016-17, 5), and it has now been completely removed from the most recent white paper (KLD 2020, 7).

Hence, despite efficiency reforms and changes in responsibilities that aim to streamline the sector, the way that we operate today is unsustainable; archaeological finds are collected, processed and stored, and the stores expand. Heritage lists keep getting made and keep getting longer - often in the name of diversity or representativeness. In the Norwegian context, the Directorate for Cultural Heritage has set as a target that 'by 2020 , each municipality will have an overview of its cultural heritage as a basis for identifying a selection of monuments, sites and environments for conservation' (2016-17, 5). In 2020, there were 356 municipalities in Norway, which implies that there ought to 
be 356 local heritage lists. In addition, the government has decided that the establishment of a list of heritage sites of national importance is to be considered.

Thus, more and more is becoming heritage, but we rarely stop to consider whether something should officially stop being heritage (Harrison 2013 , 583), or really think beyond the short-term future within heritage management (Högberg et al. 2017, 643). For example, one of the national goals of the Norwegian government white paper, Leve med kulturminner, is that 'The geographical, social, ethnic, commercial and temporal breadth of protected heritage sites and heritage environments is to be improved, and a representative selection are to be listed by 2020' (KLD 2013, 11). This is repeated in the Directorate for Cultural Heritage's Strategy 2017-2021, where it is stated that 'By 2020, a representative selection of cultural monuments, sites and environments will be protected by individual protection orders' (Directorate for Cultural Heritage 2016-17, 5). However, it is also acknowledged that 'there is a long way to go before the target of protecting a representative selection of the cultural heritage is achieved' (Directorate for Cultural Heritage 2016-17, 7). Indeed, the Director-General of the Directorate for Cultural Heritage recently remarked that the World Heritage list was 'far from complete' (Geiran 2019, my translation), and hence focused on the need to add more sites rather than reshape the list. This focus on diversity of 'things' can be seen in both Nye mål $i$ kulturmiljøpolitikken (KLD 2020, 70) and Musea i samfunnet (KUD 2021, 59), and the compulsion for listing is also reaffirmed:

As a part of the conservation strategies, comprehensive overviews of relevant cultural environment categories or themes should be produced, so that both heritage management and researchers have a shared baseline of knowledge. This can contribute to the co-ordination of priorities and measures. (KLD 2020, 73)

This focus on listing is problematic both practically and politically. In Norway, the difficulty of achieving representativeness just by adding sites to a list is tacitly acknowledged in the Directorate for Cultural Heritage's strategy (2016-17, 7), and the slow rate of progress towards representativeness was noted by the Office of the Auditor General (KLD 2013, 36). National policy and management practice is thus putting the sustainability of archaeology and heritage at risk with the continuation of policies that are in clear contrast to common definitions of heritage - including that in the Faro Convention - as mutable and conditional, rather than fixed and unchanging.

Indeed, a reconsideration of past decisions is integral to sustainability: instead of considering how we might create a more sustainable - and relevant - heritage management, one that reflects the needs of people today, we have become trapped as hoarders, unable to even consider relinquishing objects, places and practices from our grasp. Current ways of dealing with heritage cannot continue; as Fredheim has argued, 'it is not possible, nor desirable, to keep everything we might consider heritage in its present state' $(\underline{2018}, 622)$. The act of pruning and de-accessioning our museum stores and registers of heritage (Harrison 2013, 587) in fact enables the approaches that recent policy encourages and allows for past heritage decisions 'to be opened up to critical questioning regarding their relevance in the contemporary world' (Harrison 2013, 591). Instead, we see a heritage discourse that emphasises maintaining the status quo, and the primacy of materiality, tangibility and the ranking of the importance of various types of heritage. Even as we advocate a mutable idea of heritage, we are unable to implement this in our own practices. This hegemonic narrative '[justifies] the prominence of expertise' and is 'both technocratic and top-down' (Smith and Waterton 2009, 27). 


\section{Conclusion}

Despite its focus on the past, archaeology and the wider field of heritage can be said to be more about present-day values and attitudes, and thus can inform and contribute to contemporary debates such as climate change, democracy, digitalisation (cf. KLD 2020, 20 ), or any other matter of societal importance. As such, archaeologists have important things to say about a wide range of issues and we ought to perform critical interventions more willingly as part of our public role. If not, as Gonzalez Ruibal et al. argue, 'we may end up as mere facilitators, social media managers or entertainers, while others will do our work in our place' $(2018,511)$. If archaeologists are to step into the role of 'public intellectual' (Tarlow and Nilsson Stutz 2013) and influence public opinion, then, as Bonacchi $(\underline{2018}, 1659)$ has noted, there needs to be 'more substantial and profound public engagement'. It is also crucial that we as archaeologists explain the social value of archaeology and ask how archaeology can be of benefit to the public - both on the individual and community level.

In this article I have attempted to work out where we stand, and where we need to act especially in relation to policy at the national level. Recent Norwegian heritage policy has become increasingly in line with both European conventions and prevailing academic thought, but there are still hurdles to overcome in order to turn policy into practice. As such, Nye mål i kulturmiljøpolitikken sets out some worthwhile goals for archaeology, and while I would argue that they are positive and point in the direction archaeology should aim to go, they are not without difficulties and complexities, as I have discussed with reference to the literature in the previous sections.

However, none of these goals will be fully achieved - at least not to a widespread extent - without changes that both enable and encourage professional archaeology to place the public at the heart of its work; at the moment, one can argue that the professional is too inward-looking, to a large extent thinking of self-preservation and maintaining the status quo as a best possible outcome in a period of reforms and cuts. As Högberg et al. (2017) have noted, the future is only superficially engaged with, and is primarily seen as a continuation of the present rather than something that can be formed. Thus, short-term preservational thinking means that the long-term status of heritage management - such as a realignment towards a people-focused approach - is often not considered. Indeed, the critical timeframe is only ever that of the current strategy. This echoes the situation regarding dissemination on the project level, as discussed above, where long-term message is subordinate to short-term boost. This lack of engagement with the future can also be used to explain the lack of engagement with current and past practices (as encouraged by Harrison $\underline{2013})$, as noted by Högberg et al. (2017, 644):

The heritage sector lacks a thorough engagement with questions concerning the future benefits of cultural heritage. Consequently, heritage professionals do not engage in critical discussions on the relevance of present-day practices and policies in heritage management.

It is thus critical that heritage professionals - the 'experts [that] are intrinsic parts of modern democratic societies' (Hølleland and Skrede 2019b, 833) - begin to reclaim their own agency that has been minimised by heritage discourse (Skrede and Hølleland $\underline{2018}$, 86) and engage with how policy should be actively implemented in order to foster engagement, participation and interest in archaeology and heritage. The role of 
professionals as mediators and facilitators is hence essential in order to achieve policy goals. This is especially important within the Norwegian setting, where the focus of democratisation is on 'more democracy' (Hølleland and Skrede 2019a, 134), and thus on management structures that stem from elected bodies and which are under political control. National solutions in other signatories to the pan-European conventions will equally have adapted to the local situation, but the role of the professional will nevertheless be key to meeting the wider policy aims.

Hence, a key factor in achieving an archaeology that encourages and enables participation, and which is sustainable and diverse is a simultaneous rejection of the concept that 'we are all heritage experts' (Schofield 2014) and agreement with the need for a more people-centred approach. Hølleland and Skrede have discussed the concepts of contributory expertise and interactional expertise (2019b, 829), and thus I would argue that the heritage professional plays an important role in the democratising process through translating their contributory expertise into interactional expertise that the layperson can use to increase their ability to participate, both democratically and interactionally, in their heritage. As such, the gatekeeper role is turned on its head, from being a means of keeping people out, to letting them in.

The national policy goals set out in Nye mål $i$ kulturmiljøpolitikken are within reach, but require action that is tailored to the Norwegian setting. This applies to other signatories to the pan-European frameworks: the paths may be different, but the destination for each nation is the same - a more people-centred archaeology.

\section{Bibliography}

Almansa Sánchez, J. 2013 'To be or not to be? Public archaeology as a tool of public opinion and the dilemma of intellectuality', Archaeological Dialogues, 20(1), 5-

11. https://doi.org/10.1017/S1380203813000044

Almansa Sánchez, J. 2018 'New paths for the future of public archaeology?', Cuadernos de Prehistoria y Arqueología de la Universidad de Granada (CPAG) 28, 197-209.

Atalay, S. 2012 Community-based Archaeology: Research with, by and for Indigenous and Local Communities, Berkeley and Los Angeles, CA: University of California Press.

Bonacchi, C. 2018 'Public archaeology cannot just 'fly at dusk': the reality and complexities of generating public impact', Antiquity 92(366), 1659-

61. https://doi.org/10.15184/aqy.2018.231

Bonacchi, C., Bevan, A., Keinan-Schoonbaert, A., Pett, D. and Wexler, J. 2019 'Participation in heritage crowdsourcing', Museum Management and Curatorship 34(2), 166-82. https://doi.org/10.1080/09647775.2018.1559080

Council of Europe 1992 European Convention on the Protection of the Archaeological Heritage. https://www.coe.int/en/web/conventions/full-list/-/conventions/treaty/143

Council of Europe 2000 European Landscape

Convention. https://www.coe.int/en/web/conventions/full-list/-/conventions/treaty/176 
Council of Europe 2005 Council of Europe Framework Convention on the Value of Cultural Heritage for Society. https://www.coe.int/en/web/conventions/full-list/lconventions/rms/0900001680083746

Council of Europe 2018 European Cultural Heritage Strategy for the 21st

Century . https://rm.coe.int/european-heritage-strategy-for-the-21st-century-strategy-21full-text/16808ae270

Det kongelige miljøverndepartementet (KLD) 2005 St.meld. nr. 16 (2004-2005): Leve med

kulturminner. https://www.regieringen.no/contentassets/c6311a10138f40e590c81f3891c 96a87/no/pdfs/stm200420050016000dddpdfs.pdf [Last accessed: 19 April 2021].

Det kongelige miljøverndepartementet (KLD) 2013 Meld. St. 35 (2012-2013) Melding til Stortinget: Framtid med fotfeste -

Kulturminnepolitikken. https://www.regjeringen.no/contentassets/d188971bddf84055a6e 3d2161e6c3ea3/no/pdfs/stm201220130035000dddpdfs.pdf [Last accessed: 19 April 2021].

Det kongelige klima- og miljødepartement (KLD) 2020 Meld. St. 16 (2019-2020) Nye mål i kulturmiljøpolitikken - Engasjement, bærekraft og

mangfold. https://www.regjeringen.no/contentassets/35b42a6383f442b4b501de0665ec8 fcf/no/pdfs/stm201920200016000dddpdfs.pdf [Last accessed: 19 April 2021].

Det kongelige kulturdepartement (KUD) 2018 Meld. St. 10 (2018-2019) Frivilligheita sterk, sjø/vstendig, mangfaldig: Den statlege

frivilligheitspolitikken. https://www.regjeringen.no/contentassets/82a9eff104b3441d92c0 4198370a0724/nn-no/pdfs/stm201820190010000dddpdfs.pdf [Last accessed: 19 April 2021].

Det kongelige kulturdepartement (KUD) 2021 Meld. St. 23 (2020-2021) Musea i samfunnet - Tillit, ting og

tid. https://www.regjeringen.no/contentassets/573ad8ffd103469087db8ee693de5060/nnno/pdfs/stm202020210023000dddpdfs.pdf [Last accessed: 19 April 2021].

Fredheim, L.H. 2018 'Endangerment-driven heritage volunteering: democratisation or 'Changeless Change", International Journal of Heritage Studies 24(6), 619-

33, https://doi.org/10.1080/13527258.2017.1399285

Geiran, H. 2019 Umistelig arv. https://www.riksantikvaren.no/Aktuelt/Nyheter/Umisteligarv [Last accessed: 6 December 2019].

González-Ruibal, A., Alonso González, P. and Criado-Boado, F. 2018 'Against reactionary populism: towards a new public archaeology', Antiquity 92(362), 50715. https://doi.org/10.15184/aqy.2017.227

Harrison, R. 2013 'Forgetting to remember, remembering to forget: late modern heritage practices, sustainability and the 'crisis' of accumulation of the past', International Journal of Heritage Studies 19(6), 579-95. https://doi.org/10.1080/13527258.2012.678371 
Högberg, A., Holtorf, C., May, S. and Wollentz, G. 2017 'No future in archaeological heritage management?', World Archaeology 49(5), 639-

47. https://doi.org/10.1080/00438243.2017.1406398

Hølleland, H. and Skrede, J. 2019a 'Regionreformen: Demokratisering og politisering av kulturminneforvaltningen', Heimen 56(2), 127-42. https://doi.org/10.18261/issn.18943195-2019-02-05

Hølleland, H. and Skrede, J. 2019b 'What's wrong with heritage experts? An interdisciplinary discussion of experts and expertise in heritage studies', International Journal of Heritage Studies 25(8), 825-

36. https://doi.org/10.1080/13527258.2018.1552613

Kajda, K., Marx, A., Wright, H., Richards, J., Marciniak, A., Salas Rossenbach, K., Pawleta, M. et al. 2017 'Archaeology, heritage and social value: public perspectives on European archaeology', European Journal of Archaeology 21(1), 96-

117. https://doi.org/10.1017/eaa.2017.19

Kelty, C.M. 2017 'Too much democracy in all the wrong places: toward a grammar of participation', Current Anthropology 58(15), 77-90. https://doi.org/10.1086/688705

Kiddey, R. 2020 'I'll tell you what I want, what I really, really want! Open archaeology that is collaborative, participatory, public, and feminist', Norwegian Archaeological

Review 51(3), 23-40. https://doi.org/10.1080/00293652.2020.1749877

Marx, A., Nurra, F. and Salas Rossenbach, K. (eds) 2017 Europeans \& Archaeology. A survey on the European perception of archaeology and archaeological heritage, Paris:

$\mathrm{NEARCH}$. https://doi.org/10.5284/1043770

May, S. 2020 'Heritage, endangerment and participation: alternative futures in the Lake District', International Journal of Heritage Studies 26(1), 71-

86, https://doi.org/10.1080/13527258.2019.1620827

Norwegian Directorate for Cultural Heritage 2016-17 Strategy 2017-

2021. https://ra.brage.unit.no/ra-xmlui/handle/11250/2442341

Merriman, N. 2004 Public Archaeology, London:

Routledge. https://doi.org/10.4324/9780203646052

Richardson, L. 2017 'I'll give you 'punk archaeology', sunshine', World Archaeology 49(3), 306-17. https://doi.org/10.1080/00438243.2017.1333036

Schofield, J. 2014 'Heritage expertise and the everyday: citizens and authority in the twenty-first century' in J. Schofield (ed) Who Needs Experts? Counter-Mapping Cultural Heritage, Farnham, Surrey: Ashgate. 1-12.

Skrede, J. and Hølleland, H. 2018 'Uses of heritage and beyond: Heritage Studies viewed through the lens of critical discourse analysis and critical realism', Journal of Social Archaeology 18(1), 77-96. https://doi.org/10.1177/1469605317749290

Smith, L. 2006 Uses of Heritage, London:

Routledge. https://doi.org/10.4324/9780203602263 
Smith, L. and Waterton, E. 2009 Heritage, Communities and Archaeology, London: Duckworth.

Stevenson, D., Balling, G. and Kann-Rasmussen, N. 2017 'Cultural participation in Europe: shared problem or shared problematization?', International Journal of Cultural Policy 23(1), 89-106. https://doi.org/10.1080/10286632.2015.1043290

Tarlow, S. and Nilsson Stutz, L. 2013 'Can an archaeologist be a public intellectual?', Archaeological Dialogues 20(1), 1-

5. https://doi.org/10.1017/S1380203813000032

Wahlgren, K.H. and Svanberg, F. 2008 'Public archaeology as renewer of the historical museum', Public Archaeology 7(4), 241-58. https://doi.org/10.1179/175355308X389067

Waterton, E. and Smith, L. 2010 'The recognition and misrecognition of community heritage'. International Journal of Heritage Studies 16(1-2), 4-

15. https://doi.org/10.1080/13527250903441671

World Commission on Environment and Development 1987 Our Common Future, Oxford: Oxford University Press. 